\title{
THE PHILOSOPHY OF EVIL: CONSIDERATIONS ON WHY WE LOVE SHAKESPEAREAN VILLAINS
}

\author{
Rafael Campos Oliven \\ Sandra Sirangelo Maggio
}

Submetido em 16 de abril de 2019.

Aceito para publicação em 01 de agosto de 2019.

Cadernos do IL, Porto Alegre, n. ${ }^{\circ}$ 58, outubro. p. 191-206.

\section{POLÍTICA DE DIREITO AUTORAL}

Autores que publicam nesta revista concordam com os seguintes termos:

(a) Os autores mantêm os direitos autorais e concedem à revista o direito de primeira publicação, com o trabalho simultaneamente licenciado sob a Creative Commons Attribution License, permitindo o compartilhamento do trabalho com reconhecimento da autoria do trabalho e publicação inicial nesta revista.

(b) Os autores têm autorização para assumir contratos adicionais separadamente, para distribuição não exclusiva da versão do trabalho publicada nesta revista (ex.: publicar em repositório institucional ou como capítulo de livro), com reconhecimento de autoria e publicação inicial nesta revista.

(c) Os autores têm permissão e são estimulados a publicar e distribuir seu trabalho online (ex.: em repositórios institucionais ou na sua página pessoal) a qualquer ponto antes ou durante o processo editorial, já que isso pode gerar alterações produtivas, bem como aumentar o impacto e a citação do trabalho publicado.

(d) Os autores estão conscientes de que a revista não se responsabiliza pela solicitação ou pelo pagamento de direitos autorais referentes às imagens incorporadas ao artigo. A obtenção de autorização para a publicação de imagens, de autoria do próprio autor do artigo ou de terceiros, é de responsabilidade do autor. Por esta razão, para todos os artigos que contenham imagens, o autor deve ter uma autorização do uso da imagem, sem qualquer ônus financeiro para os Cadernos do IL.

\section{POLÍTICA DE ACESSO LIVRE}

Esta revista oferece acesso livre imediato ao seu conteúdo, seguindo o princípio de que disponibilizar gratuitamente o conhecimento científico ao público proporciona sua democratização.

http://seer.ufrgs.br/cadernosdoil/index

Segunda-feira, 07 de outubro de 2019. 


\title{
THE PHILOSOPHY OF EVIL: CONSIDERATIONS ON WHY WE LOVE SHAKESPEAREAN VILLAINS
}

\section{A FILOSOFIA DO MAL: CONSIDERAÇÕES SOBRE POR QUE GOSTAMOS DOS VILÕES SHAKESPEARIANOS}

\author{
Rafael Campos Oliven* \\ Sandra Sirangelo Maggio**
}

\begin{abstract}
RESUMO:
Este artigo analisa o mal enquanto uma presença constante expressa através de certos personagens na dramaturgia Shakespeariana. Baseando esta pesquisa em conceitos freudianos, procuramos verificar por que leitores e espectadores contemporâneos se identificam e até mesmo simpatizam com vilões como Iago, Ricardo III e Lady Macbeth. Oscilando entre filosofia, linguística e teoria psicanalítica, buscamos compreender o fenômeno do mal na época de Shakespeare e atualmente, e como ele se relaciona com os meandros mais íntimos de nossas mentes e com a maneira como vemos e compreendemos o mundo.
\end{abstract}

PALAVRAS-CHAVE: Shakespeare; tragédias; vilões; mal.

\begin{abstract}
:
This article analyzes evil as a constant presence expressed through certain characters in Shakespeare's dramaturgy. Basing the research on Freudian concepts, we seek to answer why contemporary readers and audiences identify with and even have sympathy for villains like Iago, Richard III and Lady Macbeth. Oscillating between philosophy, linguistics and psychoanalytical theory, we seek to understand the phenomenon of evil in Shakespeare's time and nowadays, and how it relates with the innermost meanders of our minds and the way we see and understand the world.
\end{abstract}

KEYWORDS: Shakespeare; tragedies; villains; evil.

\section{Introduction}

What is our take on evil and how does it affect us nowadays? What was its understanding in Shakespeare's time? From new policies implemented by governments to economic transactions and multinational decisions, we feel that evil nowadays might be diluted into a network of operations which affect and, at the same time, evade us. In this sense, our happiness may boil down to a positive bank account statement and the certainty of being able to make ends meet at the end of the month, as well as our imagistic projection and implicit sexual display in a postmodern society where people are expected to be and look young.

In Shakespeare's time, however, there was not this Hollywood fast-paced reality where we feel, at times, as if we were in a film in which reality corresponded to a

\footnotetext{
*Doutorando em Literaturas de Língua Inglesa pelo Programa de Pós-graduação em Letras da Universidade Federal do Rio Grande do Sul.

*** Professora de Literaturas de Língua Inglesa dos programas de Graduação e Pós-graduação em Letras da Universidade Federal do Rio Grande do Sul.
} 
cinematographic movement with different takes. Nonetheless, the entering and departing of characters from different scenes, which make them worth our most cosmopolitan dreams, was already present in Shakespeare's plays, as if trying to establish a connection with a different time and era that the author sensed and presaged but would never live to experience. It is possible that, if Shakespeare lived nowadays, he would be working for the film industry or writing soap operas for television, which leads us to the next point. Delaying a bit the question of evil, can we make his characters shake off their accumulated dust from centuries of theatrical and social conventions and spring back to life in a different scenario without compromising their usual dance and allure?

Speaking of the role of God as a male who wants to penetrate us, American psychiatrist Scott Peck states that,

I shall, however, break with tradition and use the neuter for Satan. While I know Satan to be lustful to penetrate us, I have not the least experienced this desire as sexual or creative - only hateful and destructive. It is hard to determine the sex of a snake. (PECK, 1998, p. 12)

In spite of their dreadful deeds, Shakespearean villains are so enticing that we are shocked with the realization that we empathize with them, to the point of sharing the suffering of Lady Macbeth in her vain attempts to restore a symbolic order. After all, we vicariously identified with her way of thinking before, during, and after the king's assassination.

It is possible that Shakespeare's villains have such a great impact on us because they affect us right there where we end up repressing feelings and thoughts that we all have but somehow feel guilty or ashamed to display to others. In other words, they do what we would not dare to do for several reasons: the conscience of not harming others inadvertently or on purpose, the pressure to live up to the expectation of others to show a good conduct, the fear of being punished and so on. This demand to always be good, however, can also have a negative influence on people if it is taken overboard. People can easily develop repressed feelings when they are denied the right to use their aggressiveness productively, have their own opinion about different matters or develop and express their sexuality naturally.

As regards the source of evil, Peck states that "an individual's evil can almost always be traced to some extent to his or her childhood circumstances, the sins of the parents and the nature of their heredity. Yet evil is always also a choice one has made indeed, a whole series of choices." (PECK, 1998: 126) The author further develops this line of thought when he argues that,

If evil is an illness, it should then become an object for research like any other mental illness, be it schizophrenia or neurasthenia. It is the central proposition of this book that the phenomenon of evil can and should be subjected to scientific scrutiny. We can and should move from our present state of ignorance and helplessness toward a true psychology of evil. (PECK, 1998, p.127)

Going back to the question of God brought up by Peck, ought we not to conceive it nowadays as a Ghost in the machine who works inside the system and is acknowledged every time things go right, but questioned when things go wrong or there is too much human suffering involved? Is not that its proper place in contemporary 
times, rather than being considered and treated like an omnipresent and omniscient punishing spirit as it used to be in the past?

By enacting and dealing with recurring patterns such as frustrated desires and unfulfilled hopes framed as remote remembrances, Shakespeare's plays possess a residual and poetical effect similar to distant and blurred memories or striking dreams, all of which are at the same time revealing, evasive, fleeting, and sometimes painful. Not surprisingly, by "mixing memory and desire" (ELIOT, 1999, p. 23), among other things, his plays lend themselves so well to underpinning and illustrating psychoanalytical theories, mainly Freudian ones. Moreover, similar to Gabriel García Márquez's One Hundred Years of Solitude, perhaps a subordinate idea in Shakespeare's work is that what matters in our lives is not so much what we have lived as how we have lived it, i.e., the way we experience and remember reality and what scenes and events have drawn our attention or were just dreamed up and devised by ourselves and therefore marked us significantly.

Writing about Shakespeare and the period he lived in, Spencer argues that "he had admirably used the sixteenth-century beliefs about man's nature as a mine for metaphor, as a means of describing character, and as a means of defining values by which character and action could be understood". (SPENCER, 1974, p. 93) According to this author, in Hamlet, Shakespeare had a different view of what a play could contain, and in it as well as in other subsequent tragedies "the characters and events become larger than the characters of the 1590's; they make more reverberations in our minds; they take on a symbolic and universal meaning". (SPENCER, 1974, p. 94) He concludes on this matter that

in Hamlet Shakespeare for the first time used to the full the conflict between the two views of man's nature which was so deeply felt in his age. On one side the picture of man as he should be - it was bright, orderly and optimistic. On the other was the picture of man as he is - it was full of darkness and chaos. (SPENCER, 1974, p. 94)

In this context, commenting on Machiavelli's ideas that all men are bad and morally ill and that, when founding a state and giving it laws, a governor must resort to force because the end justifies the means, Spencer states that,

It was because Machiavelli based his instructions on views like this that he so outraged sixteenth-century sensibilities. Not realizing that he had, after all, a desirable end in view - the unification of Italy - and perverting his views and character into a figure of diabolic significance, the later sixteenth-century regarded him with mixed feelings of fascination and horror. (SPENCER, 1974, p.43)

Spencer argues that Machiavelli's ideas subverted the morals and ideals, as well as the hierarchy and the order of the cosmos and of created beings, with which the sixteenth-century Elizabethan society had been raised to believe and act accordingly. His atheist view contradicted the religious mentality of that epoch, which still had some remnants and traces from the Middle Ages. Further on, the author concludes that

The sixteenth-century attacks on Machiavelli were in fact a defense, sometimes in hysterical terms, of the traditional dogma, and the hysteria may be taken as an indication that, below the surface, men realized - with a 
fascinated conviction which they were afraid to admit - that the ideas of

Machiavelli might after all be true. (SPENCER, 1974, p. 45)

Although for the analysis of Shakespeare's plays evil is best understood within the historical and literary context in which it finds itself, rather than just as a formal concept, we shall attempt, in the next section, to delimit the concept of evil within a philosophical framework.

\section{The Philosophy of Evil}

According to Paul Edwards, in The Encyclopaedia of Philosophy "the problem of evil concerns the contradiction, or apparent contradiction, between the reality of evil on the one hand, and religious beliefs in the goodness and power of God or the Ultimate on the other". (EDWARDS, 1967, p. 136) In religious terms, there is a difference between evil and sin. Whereas all sins are evil, not all evil is a sin. A lion preys and kills various types of animals, just like so many other creatures: tigers, snakes, and scorpions, for example. Their action of killing can be considered evil, but they did not choose to act like that because it is in their nature. In other words, they were simply made this way, as they were already born like that. Nonetheless, one wonders, if God is believed to exist, why it created such fearsome creatures (cf. "The Tyger", by William Blake).

As regards sins, they are all considered evil from a religious standpoint, since they are made by humans and are therefore subordinated to a choice. The Catholic faith shows more mercifulness towards offenders, while the Protestant religion believes that there is only redemption through a complete and blind faith and devotion to God, similar to Kant's imperatives. The Catholic religion preaches that, in order to believe in God and act in a good way, both God and good actions have to make sense to people through an understanding that leads to their acceptance.

Although at first attracted by Manichaeism, a doctrine which asserts the absolute dualism of good and evil through the distinction between light or spirit and darkness or matter, Saint Augustine (354-430) ends up opposing the Manichaean conception of evil as something independent and parallel to good. According to his argument, evil can be analysed as the privation, corruption, or perversion of something good, rather than being considered as having an independent reality. Augustine's line of thought, concerning the conception of Evil as privation, is that it is dependent on good because it does not have any independent existence. According to him, in The City of God, "when the will abandons what is above itself, and turns to what is lower, it becomes evil - not because that is evil to which it turns, but because the turning itself is wicked". (AUGUSTINE, 2014, p. 489) In his aesthetic conception of Evil, exposed in Confessions, what seems to be evil, when seen alone or in a limited context, can be considered a necessary element or part of a universe that, considered in its totality, is consistently good:

To thee there is no such thing as evil, and even in thy whole creation taken as a whole, there is not; because there is nothing from beyond it that can burst in and destroy the order which thou hast appointed for it. But in the parts of creation, some things, because they do not harmonize with others, are considered evil. Yet those same things harmonize with others and are good, and in themselves are good. (AUGUSTINE, 1955, p. 89) 
The different types of evil in the literature of theodicy ${ }^{1}$ are divided into four: (1) moral evil or sin, which has its origin in human beings and angels, (2) the mental agony of suffering and the physical feeling of pain, which can be caused by $\sin$ or by (3) natural evil (tsunamis, hurricanes, and so on), and (4) the metaphysical evil which corresponds to the imperfection, randomness and finite existence of all living things. The main question which underlies theodicy and the philosophical conception of evil is the following: ""Why has an infinitely powerful and good God permitted moral evil in his universe?" and "Why has an infinitely powerful and good God permitted pain and suffering in his universe?"" (EDWARDS, 1967, p. 136)

Similar to the way evil works, the snake, one of the most feared and execrated animals since primordial times, opens up space for different interpretations. Seen from afar, it may just seem like a hysterical, inoffensive and insignificant animal, trying to fight the grip of a cat or some other creature. At a closer look, it can acquire more fearful dimensions as it may threaten to attack a camera or human being. And at a very close view, it may loom and reign dreadfully, as it relentlessly and lethally pursues a mouse or another smaller creature. From its body movements and something in its genetic composition to the production of venom and its ability to drive others away, leading to its chronic loneliness and lack of alliances, all these factors question a purely rational and philosophical approach of evil. They therefore invite us to a more psychological outlook on this theme, which will be the topic of the next section.

\section{Transitions and the Disiecti Membra from the Past}

In order to analyze the phenomenon of evil in the Modern Era, and how it resonates with other historical periods, we ought to take into consideration the wider frame in which it is contained and supported. In other words, following the line of thought of Marina Warner in her lecture "Learning my Lesson", about the introduction of tuition fees in British universities and the new vertiginous models that have been imposed from top-down recently affecting both students and professors, we should bear in mind the processes, mechanisms and changes that end up "making the complicated fabric that is the ethos of an epoch and place." (WARNER, 2016, digital text)

In the Middle Ages, certain ideas and concepts that solidified and became more vivid in the Modern Age, especially in the Elizabethan and Jacobean period, were still somehow vague and loose. The phenomenon of witchcraft, for example, started in the Modern Age. In medieval times there were only sorcerers or, rather, the belief that they existed and practiced sorcery and the Catholic Church was not so fervid about them as it was in relation to witches during Inquisition.

Similarly, the belief in heaven and hell appears to have become more intense and crystallised in Elizabethan times, if compared to the Middle Ages, when they seemed to have been blended with each other, at times in an allegorical and carnival-like way (cf. certain Bosch's paintings which depict both of them). Elizabethan society was very superstitious and the belief in ghosts is very common in this period, even more than in

\footnotetext{
${ }^{1}$ Theodicy is a term commonly used in an attempt to address the question of why a good, omnipotent and omniscient God allows the manifestation of evil and human suffering in the world. The term "theodicy" was first coined in 1710 by German mathematician and philosopher Gottfried Leibniz in his work Théodicée. He argued, using the two Augustinian themes of the privative and aesthetic conception of evil, that ours is the best of all possible universes.
} 
medieval times. All these things are probably due to the new discoveries about the world and science that were taking place then.

In this sense, Hamlet's rebuke of Horatio's reaction to the Ghost, who speaks from below, that "O day and night, but this is wondrous strange!" (Hamlet, Act I, Sc.5) is quite relevant here. He admonishes him by exclaiming that "And therefore as a stranger give it welcome. There are more things in heaven and earth, Horatio, than are dreamt of in your philosophy." (Hamlet, Act I, Sc. 5) According to Rosenfield, Horatio preoccupies himself in a very catholic way about the nature of the Ghost, which for him should have either a demoniacal or divine form. Hamlet, on the other hand, "treats the ghost, moreover, in a very profane way - as something "soft", placing it thus outside the categories of the Christian faith, of Horatio's belief (your philosophy)". (Rosenfield, 1989, p. 63) (Translation ours). As she puts it:

This mental hiatus and tragic conflict conjure in filigree the disagreement of the friends Horatio and Hamlet, whose friendship is many times a dialogue of the deaf which unites and separates the still theological universe of Horatio from Hamlet's world, traversed by doubts and suspicions in relation to the legitimacy of the principles which preside the divine and human governments. (ROSENFIELD, 1989, p. 63) (Translation ours)

The more human beings learned in the Modern Ages, the more they realized they knew very little. Their old beliefs simply came apart face to so many new discoveries, some of which were the consequence of navigation, such as the discovery that the world was round. Other discoveries, such as the fact that the earth rotated around itself, was made by Galileo (E pur si muove) and the fact that the earth was not the centre of the universe and rotated around the sun was discovered by Copernicus.

The idea that the womb was a dangerous place, hence the verb to woo someone and the synonymy between the noun woe and misfortune, dates back to medieval times but became very strong in the Elizabethan period. This idea is very present in plays such as Macbeth, Hamlet and Richard III, among others, and still finds some resonance in contemporary time. Another important component of this time is that England's population was divided between two religions: Catholicism and Protestantism, since Henry VIII had broken up with the Catholic Church and created the Anglican Church. It was therefore difficult for people to decide and know which faith to follow, and one had to bear in mind the possible implications of every decision. The current and renowned literary critic Katherine Eisaman Maus argues, in her book Being and Having in Shakespeare, that

The Reformers put an end to the selling of indulgencies, the purchasing of
masses, the veneration of relics, and other practices that seem to them to
muddle the difference between spirit and matter, worship and property
transactions. In early modern England, the fraught, sometimes violent
conflicts between Catholics, Anglicans and Puritans suggest not an innocent
or blithe conflation of subjects with objects or persons with things, but a
serious religious and ethical conundrum for many of Shakespeare's
contemporaries. (MAUS, 2013:9)

However, it is not so much the discoveries of English political philosopher Hobbes (1588-1679) and Italian philosopher and political scientist Machiavelli (14691527), which indeed greatly shocked the Elizabethan mentality, but old human aspirations that the Church had hitherto managed to keep under control and that then 
emerged in the form of individual whims and evil conducts represented by villains and other characters who reinvent themselves through self-fashioning and the impersonation of different personas.

In this context, Hamlet is the epitome of, and therefore marks symbolically, the end of the Middle Ages and the beginning of the Modern Age, which corresponds to the time Shakespeare wrote. If on one hand in the Middle Ages there was a greater emphasis on the collectiveness, on the other hand in the Modern Age there is the emergence of the concept of individuality, which is very well represented in this play, and still present in our era.

In Hamlet the first word is who: who is the source of evil, with an emphasis on the individual level. In this sense, it is different from Macbeth, which starts with when, denoting that evil is a more ambiguous thing there. In Hamlet there is a strong emphasis on conscience (your uncle killed your father and married your mother; therefore, you have to avenge your father and re-establish the symbolic order). There is also a turning away from other more soap opera styled plays of the 1590's, inasmuch as things acquire here a more universal, metaphorical, and symbolic dimension.

Let us analyse, then, the symbolic dimension of Claudius, the usurping king in Hamlet, as an evil man and a silent killer. There is a certain formal construction of evil represented by him which manifests itself through a thread or chaining. It is not evident at first sight for the reader or audience that he is an evil man and thus it has to be proved throughout the play. Similar to the effect of a slow poison, his evil conduct manifests itself gradually and has to be inferred throughout the play. Evil in Hamlet is often intercepted by good actions, which makes it more difficult to pinpoint and tackle it immediately. In the end, it is only solved through a sort of collective death that spares few people. As Sears puts it,

\footnotetext{
Indeed, the pessimism of Hamlet, as we shall see, has quite a different flavor from this pious and religious doom of a wicked world. It is far more basic, penetrating, questioning. But after all is said, pessimism of whatever brand or degree is intrinsically related and has fundamentally the same origin - an emotional or logical reaction to the phenomenon of evil; and it relates the particular wrong to the universe as a whole. The crime or injustice becomes an essential part of the world in which it occurs. (SEARS, 1974, p. 41)
}

Inasmuch as there is a transition from the notion of person and community in the Middle Ages to the concept of individuality and society in the Modern Age, Hamlet precedes the more contemporary concept of subject explored by psychoanalysis and linguistics and present in the work of Freud and later coined by Lacan. It is therefore pertinent to analyse this transition of the concept of individual to the more liquid and contemporary idea of subject and postmodern society by bearing in mind the realm of dreams, different kinds of language (language stricto sensu, cinema, modern art), and the discovery of the unconscious.

Hamlet's legendary soliloquy "to be or not to be" represents this well in the passage "to die, to sleep - to sleep, perchance to dream: ay there is the rub, for in that sleep of death what dreams may come when we have shuffled off this mortal coil, must give us pause." (Hamlet, Act III, Sc. 1) The fact that we speak through fissures, i.e., dreams, lapses and jokes, as well as our body language, points towards the processes which escape from our conscious control and somehow give us away. Similarly, the fact that we are exposed to a wide range of different environments and spaces, sometimes in 
a short period of time such as a day, for example, shows the rather patchy and at times schizophrenic reality we live in nowadays.

An important aspect about this play is that Hamlet's soliloquies ${ }^{2}$ correspond to his conscience and dilacerations as an individual. We observe him struggle with his own mind and dilemmas as we ask ourselves whether he is talking out loud or conferring to the audience. His mother, Gertrude, is also on a razor's edge. She tries to appease him, but to no avail as she fails to become the figure of the idealized father, since she cannot confer him any tranquillity and a solid determination in life. Therefore, she is torn between her new husband and his demands and her son and his expectations from her.

Speaking of the father's function as a role model to the boy-child and in Hamlet, Janet Adelman argues that what he "ultimately protects against is the dangerous female powers of the night" (ADELMAN, 1992, p. 30). According to this reasoning, she states that

\begin{abstract}
The boy-child masters his fear of these powers partly through identification with his father, the paternal power who has initially helped him to achieve separation from his mother; but if his father fails him - if the father himself seems subject to her - than that protective identification fails. This is exactly the psychological situation at the beginning of Hamlet, where Hamlet's father has become unavailable to him, not only through the fact of his death but through the complex vulnerability that his death demonstrates. The father cannot protect his son; and his disappearance in effect throws Hamlet into the domain of the engulfing mother, awakening all the fears incident to the primary mother-child bond. Here as in Shakespeare's later plays, the loss of the father turns out in fact to mean the psychic domination of the mother: in the end, it is the specter of his mother, not his uncle-father, who paralyzes his will. The Queen, the Queen is to blame. (ADELMAN, 1992, p. 30)
\end{abstract}

As can be inferred from this quote, similar to the work of all great masters, Shakespeare makes use of subplots which reveal the inner work of the characters and the plot itself. In Macbeth, the inner work of the characters is even more elaborate and vivid, as we shall examine in the next section.

\title{
4 Macbeth's Psychological Effect
}

Macbeth is a grim and terrifying play as much as it has a strong tutti-frutti core and effect. The fact that we have in ourselves both good and bad, strong and weak and healthy and pathological sides oftentimes mixed together is exemplified by the witches' speech in the first scene of the first act. 'Fair is foul and foul is fair' and 'when the battle is lost and won' clearly alludes to that aspect of human nature. This can also be evinced through the unmastered realm of dreams. It is through the natural process of dreaming that not only meanings pass but also contraries come together and contradictions can take place naturally. Therefore, dreams are one way of expressing our oftentimes conflictive and mixed feelings, symbolized through the interplay of a few signifiers.

\footnotetext{
${ }^{2}$ Soliloquies correspond to the moment a character speaks to himself/herself or to the audience when no one else is present in the scene and only the reader, or the audience, can read or listen to them. Therefore, some soliloquies represent an inner monologue while others are addressed to the audience. In Shakespeare's plays, soliloquies express the conscience of a character and are related to the idea of individuality, a concept that emerges in the Modern Age.
} 
It is important to bear in mind that this play also questions the Manichean religious philosophy which opposes good to evil and has profoundly shaped Western mentality and its religious doctrines. Therefore, by placing itself and speaking from within an occidental European context and tradition, it is able to dispute and question it. At the same time as it does that, it ends up evoking, even if involuntarily, the Eastern tradition of seeing the world as a constellation of factors and causal relationships that transcend these rather fixed and opposing categories.

In Macbeth, "fair is foul and foul is fair" plays with the ambiguity of language and our mixed feelings and diffuse sentiments that go beyond language itself, transcending it from within. Moreover, similar to Yasujiro Ozu's black-and-white cult feature film Tokyo Story (1953), one feels that, in Shakespearean tragedies and especially in Macbeth, life may end up bearing a bitter or disappointing taste to it after all.

Another important thing about this play is gender relations. As Harriet Walter puts it in an interview,

There is a great liberation in playing the Shakespearean roles that weren't
written for women because where the female roles in Shakespeare are not
there principally to reflect the men, or in relation to the men, and to play parts
where your kind of preoccupation is how to run the country, how to win a
war, how to defeat your enemy, philosophical questions about men's position
in the universe, those don't get given to women in Shakespeare's plays, so it
is wonderfully liberating to do that... (WALTER, 2015, digital text) (Orality
marks removed by us)

Writing about the role of property in Elizabethan times, Maus points out that "a great deal of early modern drama, Shakespeare's included, deals with astonishing, emotionally charged, eventfully compressed, and, therefore, wildly unusual situations". (MAUS, 2013, p.14) She goes on to state that, "because of the cornucopian richness of the Shakespearean text, it is probably possible for an ingenious interpreter to find traces of an engagement with property issues in a wide swathe of his plays" (MAUS, 2013, pp.14-15) and that his "imagined worlds, while taking early modern regimes of property as a point of departure, freely invent, simplify, and exaggerate particular features of those regimes, in what might be called a "poetics of property"". (MAUS, 2013, p. 15)

Although Maurice Charney does not devote a chapter to Lady Macbeth in his book Shakespeare's Villains, his ideas about her counterpart and partner in crime are very relevant:

\footnotetext{
Macbeth as villain has some superficial resemblances to Richard, Duke of Gloucester, in his ruthless pursuit of the crown, but Macbeth has none of the jocularity and histrionic quality that Richard inherits from the Vice figure of the morality plays. Macbeth is Shakespeare's most developed experiment in the protagonist as villain-hero. Shylock and Claudius are sympathetic in individual speeches and soliloquies, but Macbeth seems to be sympathetic throughout the play because he is so acutely aware of the horrors of his crimes. His conscience always bothers him, even at the very end of the play when he is fallen into a deep despair. (CHARNEY, 2013, p. 71)
}

Why is this play, along with other Shakespearean tragedies, so interesting, if not fascinating, and still widely read and enacted nowadays? The answer probably lies in the fact that it works extremely well with unconscious structures and layers that, in a 
similar way, also affect us in our everyday life. Ranging from unseen rapports between different people to human curiosity, envy and resentments, these plans frequently stay hidden underneath our routines and habits, as well as our vigilant consciousness, threatening to come afloat. That is one of the reasons we can identify so easily with his plays even 400 years after they have been written, through their almost timeless qualities.

What are these unconscious plans then? The way we relate to other people, exemplified through the interplay of the characters in the play, is one of them. Another one has to do with human projections. Let us think about the example of the witches. They can be interpreted as a masculine projection on women which shows the fear some men have of them, very strong at the time Shakespeare wrote and still nowadays. The inner works of this play are also related to conscious as well as subconscious plans.

Evil in Macbeth amounts to human resentments, envy, unbridled ambition and unresolved feelings. It disrupts what should be a well-balanced order of things because this kind of order is, like History itself, always contingent. It cannot please everyone and is, therefore, always subject to disruptions and outbreaks.

In a lecture entitled 'The Primordial Evil: Our Daily Pride' (Translation ours) Leandro Karnal states that "vanity is condemned in the Greek tradition for being a hybris and is condemned in the Judeo-Christian tradition for being a lack of attention to the Creator". (KARNAL, 2016, digital text) (translation ours) According to him, vanity nowadays is everywhere and is no longer considered a vice or defect but rather a virtue. When Flaubert creates Madame Bovary, he puts himself in a woman's position and thinks like her. By the same token, when Shakespeare creates Lady Macbeth, a woman that has both feminine and masculine attributes, he complexifies certain issues, pointing to the fact that a similar process may also occur to any human being. We should consider that our affections at times may work like a pendulum, oscillating between masculine and feminine forces and drives. Is not our personality also composed of weak and strong aspects, as well as healthy and pathological sides? Shakespeare's Lady Macbeth shares the idea (contemporary to her time) that femininity and wish for power cannot go together. She goes to the point of making a bargain with the forces of nature, by declaring that she is ready to be "unsexed" so that she may be queen.

\section{Iago's Evil Individualism}

Evil flows like a snake swimming deeply in uncharted waters. It not necessarily has a definite purpose nor a visible cause. One of the most dreadful and at the same time fascinating Shakespearean villains is Iago. Contrary to Richard III, who finds in his deformity the perfect excuse for an unscrupulous conduct, which works as a compensatory mechanism and does not take others into account, Iago produces his own venom without a more palpable external reason, apart from his paranoia, which could at least be a little instructive as to why he acts in such an evil way.

In his introduction to the 1986 Penguin edition of Othello, Alvin Kernan points out that Desdemona and Iago are the only characters who never change in the play. According to his interpretation, both correspond, respectively, to a life and an anti-life force that "seeks anarchy, death, and darkness." (KERNAN, 1986, p. xxx) This line of thought is similar to Freud's elaboration of the concepts of Eros and Thanatos, life and death drives, in Beyond the Pleasure Principle. (FREUD, 1990) However, for Freud the death drive or instinct is not to be associated with evil, but rather a primal drive shared 
by all human beings who can sometimes use their aggressiveness destructively towards themselves or others and who have an internal side that strives to return to an inorganic state.

In Othello, the anti-life forces that centre in Iago seek the annihilation of others, and are preceded by very obscure and sinister causes. This villain is, after all, not so human. Not only does he not feel remorse for his wrongdoings and their consequences, but also there is neither a single cause nor a comprehensible or visibly rational aim for what he is doing. As Alvin Kernan puts it,

\begin{abstract}
'Honest Iago' conceals beneath his exterior of the plain soldier and blunt, practical man of the world a diabolism so intense as to defy rational explanation - it must be taken like lust or pride as simply a given part of human nature, an anti-life spirit which seeks the destruction of everything outside the self. (KERNAN, 1986, pp. xxiii-xxiv)
\end{abstract}

Iago does evil for evil's sake. He shows neither remorse nor compassion for his victims or feels any kind of guilt, as Lady Macbeth does, after perpetrating his terrible deeds. While Richard III has a physical deformation that he uses to justify his villainous conduct, Iago seems to have a mental deformation which acts on its own and does not need many external reasons to operate. Evil here has very obscure origins and seems to belong more to the realm of peevishness, stubbornness, and unwavering pride. It is also the language that, like the language of the unconscious, speaks through him. Nevertheless, it is important to bear in mind that evil also works as an alter ego that sometimes mirrors feelings and wishes that we would rather not have and that we end up repressing in deference for others.

Iago, like so many other Shakespearean villains, symbolizes the beginning of individualism, which is something that starts in the Modern Era, and precedes the subjectivism of the Contemporary Era. A more-or-less silent killer like Claudius but, and above all, Shakespeare's most intriguing, sinister and eerie villain, Iago does not have a real motive for being evil and acting the way he does, thus causing others a certain state of bewilderment and shock. The seeking of a motive for acting in an evil way is Iago's very motive. (cf. RAATZSCH, 2009) According to this author, Iago's deeds cannot be justified, but they can nevertheless be defended, since there is a logic to them.

Among all of Shakespeare's villains, Iago is probably the one most concerned with destruction for destruction's sake and the annihilation of others. Through the destruction he seeks of everything outside the self or ego, this makes him similar to the death drive principle elaborated by Freud:

\footnotetext{
or whatever else), it could be because of the resemblance between the word "Iago" and the word "ego." For just the word "ego" is connected with the concept of egoism, contemplation of Iagos's actions, too, leads to a concept the concept of Iago - which resembles the concept of egoism. (RAATZSCH, 2009, p.1)
}

More than just the death principle, or rather similar to it, Iago enjoys, in the sense of the jouissance, or almost sexual pleasure, the destruction and annihilation of others. Iago's pleasure, in this sense, is fully consummated whenever he kills someone. Unlike sex, which strives for a life principle that may never be totally consummated 
because of the death drive itself, Iago uses all his vital energy scheming and finally managing to kill others. Moreover, this destructive impulse is topped with an uncanny pride, that of someone who has been able to subvert the established order of things without being caught out. As Sears argues,

Out of Iago's self-interest grows also the second aspect of his evil nature. He must not only destroy all obstacles to his will, but he is proud of the cunning with which he devises the kind of destruction that will bring him the keenest delight. Cassio must feel the disgrace of losing the lieutenantship through his own fault. He can blame no one but himself. (SEARS, 1974, p. 206)

When Roderigo tells Iago that "I would not follow him then" (Othello, Act I, Sc. 1) referring to Iago's military obligation to serve Othello as his subordinate, Iago exclaims in an almost prancing way that,

$\mathrm{O}$, sir, content you.

I follow him to serve my turn upon him

We cannot all be masters, nor all masters

Cannot be truly followed. You shall mark

Many a duteous and knee-crooking knave

That, doting on his own obsequious bondage,

Wears out his time, much like his master's ass,

For naught but provender; and when he is old, cashiered

Whip me such honest knaves! Others there are

Who, trimmed in forms and visages of duty,

Keep yet their hearts attending on themselves,

And, throwing but shows of service on their lords,

Do well thrive by them, and when they have lined their coats,

Do themselves homage. These fellows have some soul;

And such a one do I profess myself. For, sir,

It is as sure as you are Roderigo,

Were I the Moor, I would not be Iago.

In following him, I follow but myself.

Heaven is my judge, not I for love and duty,

But seeming so, for my peculiar end;

For when my outward action doth demonstrate

The native act and figure of my heart

In complement extern, 'tis not long after

But I will wear my heart upon my sleeve

For daws to peck at; I am not what I am. (Othello, Act I, Sc. 1)

Iago's infinite enjoyment of destruction, and his not so veiled pride in it, reaches and touches a hidden chord on us, teaching us about the darker side of life and sending us back to our own not always well solved grudges and spites, not to mention our open wounds. Whereas Lady Macbeth is evil for the sake of ambition and Richard III is physically deformed and uses evil as a means of achieving and maintaining political power, Iago is probably the most viper-like character in Shakespearean drama, making Lodovico exclaim "Where is that viper? Bring the villain forth" (Othello, Act V, Sc. 2) after Iago's scam is finally brought to light.

\section{Conclusion}


Why did Shakespeare, as an author, create such evil characters as Iago, Richard III and Lady Macbeth? What did he intend with that? The first and most obvious answer that comes to mind is that, as a writer, he needed to earn a living, was serious about it, and an efficient way to do so, in the world of theatre, was to create strong characters. Unlike other writers who finished their lives destitute and only became famous after death, Shakespeare made all the arrangements and necessary effort not to end up in this situation.

Adjacent to this idea, however, is that, similar to strong dreams that keep nagging at us or stay at the back of our minds until they are elucidated, these characters mark us in different ways and produce a lasting and ensuing effect. They also do what we may have unconsciously wished to do at certain times, but would never or rarely dare to. We can also take them all as an alert that, in life, we may come across evil people who, as practical jokers or not, may do us some harm: a red light for both audiences and readers to stay alert and not trust everyone.

Moreover, art and literature have often endeavored to enter the domain of exploring, deciphering, and enlightening the hidden passages and pathways similar to the way the meanders of our mind work. We should therefore ask ourselves what are the signifying elements that produce and constitute the characters rather than where they point at.

Freud has dealt extensively with Macbeth's and Lady Macbeth's motives for acting badly. He relates their behaviour to repressed libidinous processes which end up spilling over to their actions and afterwards leading to strong repentance, as well as the feeling of having been unjustly treated and seeking compensation for it. He also points out that Macbeth and his wife are two parts of the same thing, which is equivalent to saying that they could not exist without each other. (cf. FREUD, 1997, pp. 151-166)

Macbeth starts half-way through life and death drives (thunder, rain, lightening), slowly drawing to a scenario of destruction and insidious decadence, and it ends up with some sort of order restored, a promise of life again, even if for a short period of time and a limited geographical space. Evil in this play may be taken as an end in itself, something that starts and ends without many supports. Nevertheless, if the economy of love had taken and followed a different path, it might not have been used in a different form or for other purposes.

In Macbeth, the economy of love, i.e., how much love is allotted to everyone and how it is allotted, in an implicit exchange of matter (semen, blood and other fluids) as well as feelings, can be quite illuminating. This is because it relates directly to our lives and how we deal with love and affection, pointing to the fact that any kind of exchange can be rewarding (intelligent thoughts, presents, sex, etc.) as well as unwelcome (bad influences, indoctrination or even sweets when we want to avoid them). The fact that these things may end up affecting us points to certain fears we have of contamination. Moreover, when we talk about feelings and their consequences, we should ask ourselves what is implicit in them and what they ultimately entail.

Good and evil can only acquire a symbolic existence by means of a definition, through language, of a certain kind of perception of a specific action or set of actions. They are not necessarily binary things as many would like others to believe and as we are exposed to in some soap operas or in clear-cut cases such as Nazism or the Japanese invasion of China. On the contrary, they constitute a problematic theme which involves 
a range of issues and exposes ourselves to our very fragments, shortcomings, and different facets, as well as our repressed feelings.

Evil leaves us naked, wondering how much of us is representation and exposing ourselves to our very own wounds, forebodings and unsolved problems. Analysing and writing about evil will never provide us with the bird's view from the top of a mountain. Rather, it corresponds to a dive into the depths of the human soul, which may easily prove to be quite contradictory or even illogical. It acts out the very twists and turns of the soul and its multiple facets and patterns, possible reactions to the violence and contingencies of the world itself. In the end, we might be confronted with the terrifying sea snake, albeit having, consciously or unconsciously, tried as hard as possible to avoid it, because, after all, it is just evil in its pure form, rather than come across the beautiful shoal of fish we had so willingly hoped for.

\section{REFERENCES}

ADELMAN, Janet. Suffocating mothers. London: Routledge, 1992.

AUGUSTINE, Aurelius. Confessions. Tradução: Albert Outler. Dallas: Outler, 1955. Disponível em: https://www.ling.upenn.edu/courses/hum100/augustinconf.pdf [27 fev. 2018]

The city of God, Volume II. Tradução: Albert Outler. Edinburgh: Marcus Dodds, 2014. Disponível em: https://www.gutenberg.org/files/45304/45304-h/45304h.htm [15 fev. 2014]

CHARNEY, Maurice. Shakespeare's villains. Plymouth: Fairleigh Dickinson University Press, 2013.

EDWARDS, Paul. The encyclopedia of philosophy. New York: Macmillan, 1967.

ELIOT, T. S. The waste land and other poems. London: Faber and Faber, 1999.

FREUD, Sigmund. Beyond the pleasure principle. Tradução: Alix Strachey. New York: W.W. Norton and Company, 1990. (1920)

Writings on art and literature. Tradução: Alix Strachey. Stanford: Stanford University Press, 1997.

KARNAL, Leandro. Interview. Disponível em: https://www.youtube.com/watch?v=cpxVd5whW9U [29/02/2016]

KERNAN, Alvin. "Introduction". In: SHAKESPEARE, William. Othello. New York: Penguin, 1986.

MAUS, Katharine Eisaman. Being and having in Shakespeare. Oxford: Oxford University Press, 2013. 
NEILL, Michael. "Money man". In London Review of Books: Volume 36, number 3, 6 February 2014.

PECK, M. Scott. People of the lie: the hope for healing human evil. New York: Simon and Schuster, 1998.

RAATZSCH, Richard. The apologetics of evil: the case of Iago. Princeton: Princeton University Press, 2009.

ROSENFIELD, Kathrin H. A linguagem liberada. São Paulo: Perspectiva, 1989.

SHAKESPEARE, William. Macbeth. New York: Penguin, 2000.

The complete works. Edited by Stanley Wells and Gary Taylor. Oxford: Oxford University Press, 2005.

. The tragedy of King Richard III. New York: Penguin, 2000.

. The tragedy of Othello the Moor of Venice. New York: Penguin, 2001.

. The tragic history of Hamlet prince of Denmark. New York: Penguin, 2001.

SEARS, Lloyd Cline. Shakespeare's philosophy of evil. North Quincy: Christopher Publishing House, 1974.

SPENCER, Theodore. Shakespeare and the nature of man. New York: Macmillan, 1974.

WALTER, Harriet. Interview. Disponível em: https://www.youtube.com/watch?v= XHofH6z9mzU. [10 out 2016]

WARNER, Marina. Lecture. Disponível em:

https://www.youtube.com/watch?v=m7jK81Q6k2w. [30 set 2016] 